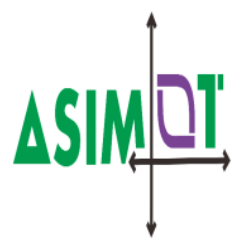

ASIMTOT: JURNAL KEPENDIDIKAN MATEMATIKA

Volume 1 Nomor 1, Januari - Mei 2019, halaman 13 - 17

Tersedia Daring padahttps://journal.unwira.ac.id/index.php/Asimtot

\title{
PENGARUH KECERDASAN EMOSIONAL TERHADAP PRESTASI BELAJAR MATEMATIKA PADA SISWA SMP KELAS VIII
}

\section{THE EFFECT OF EMOTIONAL INTELLIGENCE ON THE LEARNING ACHIEVEMENT OF CLASS VIII JUNIOR HIGH SCHOOL}

\author{
Rofyanter leoh, Kristoforus Djawa Djong, Meryani Lakapu
}

Universitas Katolik Widya Mandira

rofleo41@gmail.com, djongdeflores@gmail.com, meryanilakapu@gmail.com

\begin{abstract}
Abstrak: Penelitian ini bertujuan untuk mengetahui ada tidaknyanya pengaruh kecerdasan emosional terhadap prestasi belajar siswa SMP kelas VIII. Jenis penelitian ini adalah penelitian kuantitatif. Populasi dalam penelitian ini adalah semua siswa kelas VIII SMPN 2 Kota Kupang dan sampel penelitiannya yaitu siswa kelas VIII D dengan teknik pengambilan sampel ialah simple ramdom sampling. Teknik pengumpulan data menggunakan angket dan tes prestasi belajar matematika. Analisis data dilakukan dengan dua cara yaitu program SPSS 16.0 for windows. Dari hasil analisis, berdasarkan uji normalitas, liniaritas, signifikansi, kecerdasan emosional mempunyai pengaruh terhadap prestasi belajar matematika dan di peroleh persamaan regresi $\mathrm{Y}=1,737 \mathrm{X}$ 41,796 dan nilai t_hitung $=4,953>2,052=$ ttabel maka, tolak H0artinya ada pengaruh secara signifikan kecerdasan emosionalterhadap prestasi belajar.Berdasarkan hasil penelitian, peneliti menyimpulkan bahwa Ada pengaruh yang signifikan kecerdasan emosional terhadap prestasi belajar matematika siswa kelas VIII SMPN 2 Kota Kupang.
\end{abstract}

Kata Kunci: Kecerdasan Emosional, Prestasi Belajar.

Abstract: This study aims to determine the effect of emotional intelligence on the learning achievement of class VIII junior high school.This type of research is quantitative research.The population in this study is all students of class VIII SMP N 2 Kupang and the research sample is class VIII D students with the sampling technique is simple ramdom sampling. Data collection techniques using questionnaires and mathematics learning achievement tests. Data analysis was carried out in two ways, namely the SPSS program.From the results of the analysis, based on the tests of normality, linearity, significance, emotional intelligence has an influence on mathematics learning achievement and was obtained by equation of regression $Y=0,642 X$ and $t$-count $=$ 4.272> 2, $052=t$ table then, a push HO, it means that there is a significant effect of emotional intelligence on learning achievement. Based on the results of the study, the researcher concluded that there was a significant effect of emotional intelligence on mathematics learning achievement of class VIII students of SMPN 2 Kota Kupang.

Keywords: emotional intelligence, learning achievement

Cara Sitasi: Rofyanter, M.L., Kristoforus, D,J. \& Meryani, L.. (2019). Pengaruh kecerdasan Emosional Terhadap Prestasi Belajar matematika Pada Siswa SMP Kelas VIII. Asimtot: Jurnal Kependidikan Matematika, $1(1), 13-18$ 
Pada zaman sekarang ini, seseorang dituntut untuk sukses di bidang akademik, handal dalam kepemimpinan, mampu berkomunikasi terbuka dan jujur, memiliki loyalitas dan kreativitas untuk selalu berinovasi. Hal ini diperlukan dalam rangka menghadapi era yang penuh dengan perubahan, semakin canggih dan penuh persaingan. Sesuai dengan Undang-Undang No. 20 tahun 2003 tentang sistem pendidikan nasional menyatakan bahwa tujuan pendidikan nasional adalah mencerdaskan kehidupan bangsa dan mengembangkan manusia Indonesia seutuhnya yaitu manusia yang bertakwa kepada Tuhan Yang Maha Esa dan berbudi pekerti luhur, memiliki pengetahuan dan keterampilan, kesehatan rohani dan jasmani, kepribadian yang mantap dan mandiri serta tanggung jawab kemasyarakatan dan kebangsaan, maka dengan itu untuk mencapai tujuan pendidikan nasional diperlukan peran serta pihak-pihak terkait

Prestasi belajar menurut kamus besar bahasa Indonesia adalah hasil yang telah dicapai dari penguasaan pengetahuan atau keterampilan yang dikembangkan melalui mata pelajaran yang lazimnya ditunjukkan dengan nilai tes atau angka nilai yang diberikan guru. Prestasi belajar menunjuk pada kinerja belajar seseorang yang umumnya ditunjukan dalam bentuk nilai rata-rata yang maka dapat disimpulkan bahwa bahwa prestasi belajar adalah tingkat keberhasilan siswa dalam mengikuti kegiatan pembelajaran yang dapat diketahui melalui tes, ujian, ulangan dalam bentuk nilai (Latipah, 2010). Berdasarkan hasil pengamatan pada saat melakukan praktik pengalaman lapangan (PPL) di SMPN 2 Kupang, sebagian besar siswa kelas VIII menganggap mata pelajaran matematika sebagai mata pelajaran yang sulit dipahamidan sebagai suatu pelajaran yang menakutkan hal ini ditunjukan dengan persentase data ketuntasan ulangan mid semester ganjil tahun ajaran 2018/2019 yaitu kelas VIII D $12 \%$ dari 31 siswa, kelas VIII E $8 \%$ dari 35 siswa dan kelas VIII F 3\% dari 35 siswa.

Berkaitan dengan hal di atas, maka dipandang perlu upaya-upaya perbaikan yang dapat meningkatkan prestasi belajar matematika dengan melakukan suatu pengkajian secara sistematis mengenai faktorfaktor yang mempengaruhi prestasi belajar matematika. Yang mempengaruhi sukses belajar dapat digolongkan menjadi dua faktor yaitu: faktor internal dan faktor eksternal (Ula, 2013). Faktor internal yang dimaksud disini salah satunya adalah kecerdasan emosional.

Kecerdasan emosional merupakan hubungan antara perasaan, watak, dan naluri moral yang mencakup pengendalian diri, semangat dan ketekunan, kemampuan menyesuaikan diri, kemampuan memecahkan masalah pribadi, mengendalikan amarah serta kemampuan untuk memotivasi diri sendiri (Firdaus, 2012). Kecerdasan emosional adalah kemampuan mengendalikan, memahami dengan efektif menerapkan kekuatan dan ketajaman emosi sebagai sumber energi, informasi dan pengaruh (Rohiat, 2011). Ada lima wilayah kecerdasan emosional yaitu kemampuan mengenali emosi diri, kemampuan mengelola emosi, kemampuan memotivasi diri, kemampuan megenali emosi orang lain, kemampuan membina hubungan (Hamza dan Masri, 2010)

Dalam pembelajaran matematika, kecerdasan emosional merupakan suatu hal 
yang diperlukan oleh siswa. Kecerdasan emosional juga mempengaruhi sikap belajar matematika siswa, sesuai dengan kemampuan memanfaatkan emosi secara produktif (Goleman, 1996). Siswa tidak mampu mengontrol gejolak emosinya dengan baik maka siswa akan cenderung putus asa dan mudah menyerah. Selain itu jika siswa tidak memiliki hubungan yang baik dengan teman dan guru maka ketika siswa menemui masalah yang berkaitan dengan pelajaran siswa akan merasa malu dan canggung untuk bertanya sehingga mengurangi kemampuan siswa siswa untuk menemukan solusi dari masalah yang dihadapinya.

\section{Metode Penelitian}

Dalam penelitian ini terdapat dua variabel yang merupakan variabel bebas yaitu kecerdasan Emosional $(\mathrm{X})$ dan variabel terikat yaitu Prestasi Belajar Matematika (Y)

Populasi dari penelitian ini adalah siswa kelas VIII SMP Negeri 2 Kota Kupang yang terdiri dari 10 kelas. Sedangkan Sampel dari penelitian ini adalah seluruh siswa kelas VIII DSMP Negeri 2 Kupang. Teknik pengambilan sampel yang digunakan adalah simple random sampling, dikatakan simple (sederhana) karena pengambilan anggota sampel dari populasi dilakukan secara acak tanpa memperhatikan strata yang ada dalam populasi itu (Sugiyono, 2014).

Instrumen yang digunakan dalam penelitian ini berupa tes prestasi belajar dan angket. Tes prestasi belajar digunakan untuk memperoleh skor prestasi belajar matematika dan angket digunakan untuk mengambil data variabel kecerdasan emosional.Angket ini terdiri atas option, sangat setuju (SS), setuju (S), tidak setuju (TS) dan sangat tidak setuju (STS). Butir-butir pernyataan dari angket dibuat dalam bentuk positif dan negatif. Nilai skala dari pernyataan positif sebagai berikut : 4 untuk SS, nilai 3 untuk S, nilai 2 untuk TS, dan nilai 1 untuk ST. Sebaliknya, untuk pernyataan negatif dibalik menjadi 1 untuk SS, nilai 2 untuk S, nilai 3 untuk TS, dan nilai 4 untuk STS. Teknik analisis data dalam penelitian ini ialah Statistik inferensial yang bertujuan untuk menguji hipotesis. Untuk keperluan tersebut digunakan analisis regresi linear sederhana dengan bantuan program SPSS 16.0 for windows. Jenis data dalam penelitian adalah data primer. Data primer adalah data yang diperoleh secara langsung dari subjek penelitian (Sugiyono, 2014)

\section{Hasil Penelitian dan Pembahasan}

\section{Hasil}

1. Uji Normalitas

Bukti normalitas bertujuan untuk mengetahui apakah suatu sampel acak berukuran $\mathrm{n}$ berasal dari populasi yang berdistribusi normal atau tidak, sehingga analisis regresi dapat dilaksanakan (Siregar, 2013). 
Berdasarkan hasil analisis uji normalitas untuk variabel $\mathrm{X}$ (Kecerdasan Emosional) dengan $\alpha=0.05$ pada output SPSS 16.0 for windows diperoleh nilai Sig $=0.199>0.05=$ anormal atau $\mathrm{D}_{\text {hitung }}=0.136<0.254=\mathrm{D}_{\text {tabel }}$ maka terima $\mathrm{H}_{0}$ yang berarti data berdisrtibusi normal.

Berdasarkan hasil analisis uji normalitas untuk variabel Y(prestasi belajar) pada output SPSS 16.0 for windows diperoleh nilai Sig. = $0.126>0.05=$ aatau $\mathrm{D}_{\text {hitung }}=0.147<0.254=$ $\mathrm{D}_{\text {tabel }}$ maka terima $\mathrm{H}_{0}$ yang berarti data berdisttibusi normal

\section{Uji Linearitas}

Berdasarkan hasil analisis uji linearitas variabel X terhadap Y pada output SPSS 16.0 for windows, diilihat dari nilai signifikansi pada Deviation for Linearity $=0.780>0.05=\alpha$ dan diperoleh nilai $\mathrm{F}_{\text {hitung }}$ yaitu $=0.660$ dengan $\alpha=$ 0.05 , df $1=1$ dan df $2=26$. Hasil perhitungan di peroleh nilai $F_{\text {tabel }}=4,23$. Karena nilai signifikansi $=0.780>0.05=\alpha$ dan $\mathrm{F}_{\text {hitung }}=$ $0,660<4,23=F_{\text {tabel }}$ maka terima $\mathrm{H}_{0}$ dan dapat disimpulkan bahwa antara variabel $\mathrm{X}$ dan $\mathrm{Y}$ terdapat hubungan yang linear

\section{Uji hipotesis}

Berdasarkan hasil output SPSS 16.0 for windowsdiperoleh uji $t_{\text {hitung }}=4,953$ dengan signifikansi 0,000 , dan di dapat $t_{\text {tabel }}=2,055$ berdasarkan kriteria di atas maka 4,953= $t_{\text {hitung }}>2,055=t_{\text {tabel }}$. Dengan demikian tolak $\mathrm{H}_{0}$ dan terima $\mathrm{H}_{\mathrm{a}}$ berarti Ada pengaruh secara signifikan kecerdasan emosionalterhadap prestasi belajar siswa SMP kelas VIII dan berarti juga bahwa model regresi linear sederhana $\mathrm{Y}=1,737 \mathrm{X}$ - 41,796 layak secara statistik digunakan baik secara alat penaksir maupun sebagai peremal. Nilai koefesien $\mathrm{R}^{2}=0,486$ menunjukan bahwa 48,6\% variansi total prestasi belajar siswa SMP kelas VIII dipengaruhi oleh kecerdasan emosional

\section{Pembahasan}

Kecerdasan emosional mencakup
kesadaran diri dan dorongan kendali hati,
ketekunan, semangat dan motivasi diri, empati
dan kecakapan sosial. Siswa yang mempunyai
kecerdasan emosional yang baik akan mampu
mengenal siapa dirinya, mengendalikan dirinya,
memotivasi dirinya, berempati terhadap
lingkungan sekitar dan memiliki keterampilan
sosial. Oleh karena itu, kecerdasan emosional
sangat berperan penting dalam keberhasilan hidup
seseorang termasuk pada diri seorang siswa.

\section{Simpulan dan Saran}

\section{Simpulan}

Berdasarkan hasil analisis dan data dan pembahasan, dapat disimpulkan sebagai berikut :

Ada pengaruh yang signifikan kecerdasan emosional terhadap prestasi belajar matematikasiswa kelas VIII SMPN 2 Kota Kupang.

\section{Saran}

Berdasarkan kesimpulan diatas maka disankan kepada guru atau tenaga pendidikan untuk selalu memperhatikan kecerdasan emosional untuk dapat meningkatkan prestasi belajar siswa.

\section{Daftar Pustaka}

Badan pengembangan dan pembina bahasa. 2005. Kamus besar bahasa Indonesia. Jakarta: Balai pustaka

Daud, Firdaus. 2012. Pengaruh Kecerdasan Emosional dan Motivasi Belajar terhadap Hasil Belajar Biologi Siswa SMA 3 Negeri Kota Palopo: Jurnal Pendidikan dan Pembelajaran Vol.19 (2) 
Goleman, D. 1999. Emotional Intelligence. Jakarta: Gramedia Pustaka Utama

Hamza dan Masri. 2010. Mengelola Kecerdasan Emosional Dalam Pembelejaran. Jakarta: Bumi Aksara

Latipah, Eva. 2010. Strategi Self Regulated Learning dan Prestasi Belajar. Jurnal Psikologi Vol.37 (1), 110-129

Pemerintah Indonesia. 2013. Undang-Undang Nomor 20 Tahun 2013 Tentang Sistem Pendidikan Nasional. Lembaran RI Tahun 2013 No 20. Jakarta: Sekretariat Negara

Rohiat. 2011. Kecerdasan Emosional Kepemimpinan Kepala Sekolah. Bandung: Refika Aditama

Siregar, S. 2013. Metode Penelitian Kuantitatif. Jakarta: Kencana

Sugiyono. 2014. Metode Penelitian Pendidikan. Bandung: Alfabeta

Ula, Shoimantul. 2013. Buku Pintar Teoriteori Manajemen Pendidikan Efektif. Yokyakarta: Berlian 